\title{
Pongamia (Pongamia pinnata): a sustainable alternative for Biofuel Production and Land Restoration in Indonesia
}

\author{
Budi Leksono ${ }^{1}$, Syed Ajijur Rahman 2, *, Deki A Purbaya ${ }^{3}$, Yusuf B Samsudin 2, Soo Min Lee 4, \\ Siti Maimunah ${ }^{5}$, Agus M Maulana ${ }^{2}$, Jaya Wohono ${ }^{6}$, Himlal Baral ${ }^{2}$ \\ 1 Center for Forest Biotechnology and Tree Improvement (BIOTIFOR), The Forestry and Environmental \\ Research, Development and Innovation Agency (FOERDIA); boedyleksono@yahoo.com \\ 2 Center for International Forestry Research (CIFOR), Bogor (Barat) 16115, Indonesia; \\ S.Rahman@cgiar.org (SAR),Y.Samsudin@cgiar.org (YBS), A.Maulana@cgiar.org (AMM), $\underline{\text { H.Baral@cgiar.org }}$ \\ (HB) \\ 3 Center for Climate Change and Forest and Land Fire Control (Balai PPIKHL) Sumatra Region Office, \\ Ministry of Environment and Forestry, Indonesia; andikadeki100@yahoo.com \\ 4 National Institute of Forest Science, Seoul 02455, Republic of Korea; lesoomin@gmail.com \\ 5 Faculty of Agriculture and forestry, University Muhammadiyah Palangkaraya (UMP), Central Kalimantan \\ 73111, Indonesia; sitimararil@gmail.com \\ ${ }^{6}$ Clean Power Indonesia, Graha Mitra 8th Floor, Jl Gatot Subroto 24, Jakarta 12930, \\ Indonesia; j.wahono@cleanpowerindonesia.com \\ * Correspondence: S.Rahman@cgiar.org; Tel.: +62-251-8622-622
}

\begin{abstract}
Indonesia has a large area of degraded land, i.e. 30 million ha, which could potentially be utilized for biofuel plantations. The leguminous tree pongamia (Pongamia pinnata syn. Milettia pinnata) could be utilized to produce biofuel while restoring degraded land. Here, we explore the potential of pongamia as a source of biofuel and for restoring degraded land in Indonesia. Pongamia occurs across Indonesia, in Sumatra, Java, Bali, West Nusa Tenggara and Maluku. It grows to a height of 15-20 m and can grow in a range of environmental conditions. Its seeds can generate up to $40 \%$ crude oil by weight. It can help to restore degraded land and improve soil properties. Pongamia also provides wood, fodder, medicine, fertilizer and biogas. Therefore, as a multipurpose species, pongamia holds great potential to combat Indonesia's energy crisis and to restore much of the degraded land.
\end{abstract}

Keywords: Indonesia, biofuel, land restoration, pongamia

\section{Introduction}

An ever-increasing energy demand has raised the importance of new and renewable sources of energy [1,2]. Petroleum fuel is the primary source of energy used by communities in Indonesia to run their cars, and many other types of vehicles that need petroleum fuel to operated, such as boats and agricultural tractors [1]. In recent years, Indonesia has switched from being a petroleumexporting to a petroleum-importing country and, by 2030, its own natural reserves will be depleted and unable to support demand [2]. This realization has highlighted the need to find and develop alternative sources of energy. Biofuel is considered to be an important alternative source of energy [2]. Therefore, the Indonesian government's national energy policy supports new and renewable energy, which could provide up to $23 \%$ of national energy needs by 2025 and $31 \%$ by 2050 [3].

Globally, at present, biofuel is mostly obtained from oil palm, coconut, cassava, corn, sorghum and other edible food plants. Non-edible energy sources, e.g. jatropha (Jatropha curcas), have also been introduced, but require fertile land to achieve high yields and the resulting competition with food and cash crops limits its overall production prospects [4]. Therefore, there is an urgent need to 
identify non-edible plant species that can be used as an energy source and can grow on abandoned lands, i.e. marginal or degraded lands. Pongamia (Pongamia pinnata syn. Milettia pinnata) is such a species: its seeds are valued for their biofuel properties and it can grow in a marginal land [5].

Indonesia has a large area of degraded and marginal lands. The Ministry of Environment and Forestry has identified 30 million ha of degraded lands [6]. Several government agencies in Indonesia have land restoration targets, including the Peatland Restoration Agency (Badan Restorasi Gambut, BRG) that aims to restore more than 2 million ha of degraded peatland in Riau, Jambi, South Sumatra, West Kalimantan, Central Kalimantan, South Kalimantan and Papua [7]. Restoring some of these lands using suitable biofuel species (e.g. pongamia) can provide an opportunity to enhance ecosystem services [8,9] and support local economies [10-12]. Pongamia grows naturally in Indonesia and can survive on degraded land. This review provides information on its distribution, growth, yields, biofuel potential and land restoration capacity to corroborate scientific understanding. It provides a valuable resource that practitioners and policymakers can use in planning projects [13-15].

\section{Materials and Methods}

This study is based on a robust and thorough literature review of both the peer-reviewed and grey literature. Using selected key words and phrases (Table 1), relevant literatures were gathered from the internet using scientific research search sites, i.e. Google Scholar, Mendeley, Scopus and Web of science. The review was conducted from January to September 2018. At the outset of the review, the inclusion criteria (Table 1) were necessarily rudimentary to gather targeted information of pongamia. Therefore, we have conducted a quick review of the abstracts and contents of the retrieved literatures to evaluate their relevance to be included for extensive review for our study. While we did not expect literature that can report all of the relevant information, we have developed an Excel database to capture any relevant information found during the literature screening process, to enhance consistency and effective analysis.

Table 1. Search sites, key words and inclusion criteria to generate targeted information from literature review used in this study

\begin{tabular}{|c|c|c|}
\hline Search sites & Key words and search phrases & Inclusion criteria \\
\hline $\begin{array}{l}\text { Google Scholar. } \\
\text { Mendeley. } \\
\text { Scopus. } \\
\text { Web of science. }\end{array}$ & $\begin{array}{l}\text { 'pongamia', 'bioenergy', 'biofuel', 'jet fuel', } \\
\text { 'pongamia and bioenergy', 'pongamia and } \\
\text { biofuel', 'pongamia oil', 'bioenergy and } \\
\text { Indonesia', 'biofuel and Indonesia', } \\
\text { 'pongamia, bioenergy and Indonesia', } \\
\text { 'pongamia, biofuel and Indonesia', 'pongamia } \\
\text { and land restoration', 'pongamia, land } \\
\text { restoration and Indonesia', 'pongamia and } \\
\text { nitrogen', 'pongamia, land restoration and } \\
\text { nitrogen', 'pongamia benefit', 'potential of } \\
\text { pongamia', 'pongamia wood', 'pongamia } \\
\text { medicine', 'pongamia agroforestry', } \\
\text { 'pongamia based agroforestry', 'pongamia } \\
\text { landscape'. }\end{array}$ & $\begin{array}{l}\text { Evidence based information } \\
\text { of pongamia, i.e. } \\
\text { distribution, growth, yields, } \\
\text { biofuel potential, land } \\
\text { restoration capacity. }\end{array}$ \\
\hline
\end{tabular}

The relevant information was carefully compiled point-by-point, and scientific interpretation was made by using the narrative qualitative and narrative comparative analysis method. The analysis process is designed to scrutinize relevant concepts from textual data in a transparent subjective way. 
Careful attention was paid for a more discursive interpretation and to represent a view of reality through a process of decontextualization and recontextualization with appropriate scientific order as presented in section 3 below.

\section{Results and Discussion}

\subsection{Potential of pongamia as a biofuel species}

\subsubsection{Distribution}

Pongamia is a humid and sub-tropical plant. It grows in a wide range of agro-climatic conditions. Although native to India, China, Pakistan, Sri Lanka, Vietnam, Malaysia, Indonesia, Japan, Fiji and Australia, it has gradually been introduced to Egypt, United States, Puerto Rico and many African countries. It is commonly called Indian beech, Karum tree (English); pongam (Gujarat); dalkaramch (Tamil Nadu); karanj, karanja, kanji (Hindi); kanuga oil tree (Telugu); honge (Kannada); shui huang pi (China); day mau (Vietnamese); kranji, malapari (Indonesian); mempari (Malay) $[17,18]$. In Indonesia, pongamia occurs mostly in the western part of Wallace line while some also can be found in the eastern part of the line: Berbak, Sembilang National Park, South Sumatra province; Berikat gulf, Bangka Belitung Province; Cape Lesung, Banten Province; Batu Karas, Pangandaran, West Java Province; Ujung Blambangan, Alas Purwo National Park, Baluran National Park, East Java province; Lovina, North Bali, Bali province; Senipah, Samboja, Sekerat, Tanjung Batu, East Kalimantan province; Sembelia, East Lombok, West Nusa Tenggara Province; and in West Seram Island, Maluku Province (Figure 1) [15,18-20]. Pongamia has many local names in Indonesia, e.g. malapari (Simeulue island), mabai (Bangka island), ki pahang laut (East Java), bangkongan and kepik (Java island), kranji (Madura island), marauwen (Minahasa, Sulawesi island), hate hira (Ternate island), butis and sikam (Timor island) [15].

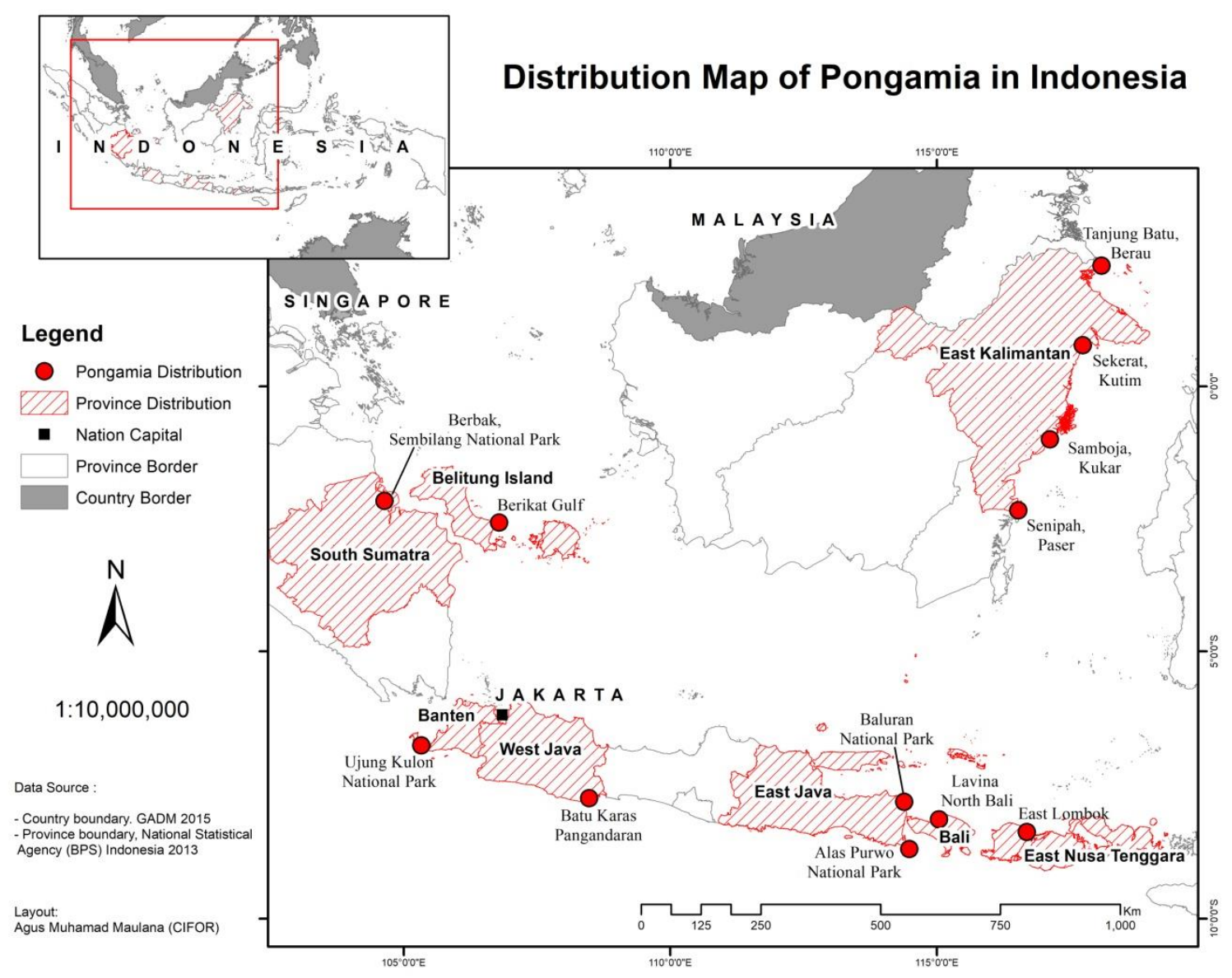


Figure 1. Natural distribution of Pongamia pinnata in Indonesia

\subsubsection{Growth}

Pongamia naturally grows well in lowland forests on calcareous soils, in rocky beach areas, along the edges of mangrove forests, and along streams and estuaries. It is a hardy woody plant and can survive in temperatures ranging from $5^{\circ} \mathrm{C}$ to $50^{\circ} \mathrm{C}$ and at altitudes of $0-1200 \mathrm{~m}[20,21]$. It grows well in both full sun and partial shade, and can grow in most soil types, from stony to sandy to clayey. Although it is tolerant of salinity, it does not survive well in dry sands [16].

Pongamia is a semi-deciduous tree whose seeds contain non-edible oil, which can be processed into biodiesel. It is a forest tree, demands only low levels of moisture, it is drought resistant, and needs minimum input and management to grow [17,21]. It grows $15-20 \mathrm{~m}$ high and has a large and wide canopy [17]. With its rapid growth rate, it can reach its adult height $(15-20 \mathrm{~m})$ within $4-5$ years [22]. Flowering usually starts after $4-5$ years.

Pongamia can be propagated by generative or vegetative means. It can be vegetatively propagated from cuttings and root suckers (with new plants growing from lateral roots of the parent tree) to produce trees that are genetically identical to the parent trees [23]. Pongamia is also propagated by seeds in nursery beds or polybags, and via in-situ sowing of seeds in plantations $[5,24]$. It is also reported that seeds stored for three months or more result in less germination and plant vigor [24]. Seed take about one week to germinate and about $85 \%$ of seeds germinate with appropriate nursery management. There is also finding on direct relationship between seed size and germination efficiency, but only for fresh seeds [5]. The long-term viability of pongamia trees also depends on appropriate pruning practices.

\subsubsection{Yields}

Pongamia produces large quantities of seeds, however, yields vary according to country and environmental conditions [16,17,25-28]. There is limited information about the seed yields of pongamia in Indonesia, and most of the literature on the yields of pongamia seeds is from India and Australia [25,27-29]. This is because, pongamia grows naturally or in plantations in a wide range of areas in India while the State of Queensland is a common place for pongamia cultivation in Australia $[5,27]$.

Pongamia can produce up to $90 \mathrm{~kg}$ of seeds per tree with a minimum of $9 \mathrm{~kg}$ per adult tree annually in India, equivalent to a potential yield of between 900 and $9000 \mathrm{~kg}$ per hectare [17]. This is higher than the yields reported in Australia of between $20 \mathrm{~kg}$ and $80 \mathrm{~kg}$ per tree [29]. Another report noted that, in Australia, the average annual seed production is $20 \mathrm{~kg}$ per tree [27]. In peninsular India, seed yields per tree range from $10 \mathrm{~kg}$ to more than $50 \mathrm{~kg}$ [28]. In Bangladesh young pongamia (15 years old or less) produce more than $25 \mathrm{~kg}$ of seeds per tree per year, however, yields increase as trees grow older, i.e. annual yields is more than $100 \mathrm{~kg}$ for 20 -year-old trees and $300-500 \mathrm{~kg}$ for trees older than 30 years [30]. As the pongamia tree can survive up to 100 years, its production increases every year; and minimum maintenance is needed once trees reach 30 years in age [30].

\subsubsection{Biofuel production potential}

The most useful product from pongamia is biodiesel. Biodiesel is produced by the transesterification of bio-oil using a catalyst (e.g. potassium hydroxide $(\mathrm{KOH})$ or sodium hydroxide $(\mathrm{NaOH}))[30]$. The biodiesel produced is a clean burning fuel that has no sulfur emissions and is noncorrosive. At low pressure and temperature, transesterfication produces $80 \%$ methyl ester, and $20 \%$ glycerin as by-product [17]. The major fatty acids in Pongamia pinnata crude oil are palmitic acid, stearic acid, linoleic acid and eicosenoic acid. The pongamia oil extracts exhibit good chemical properties and could be used as good biodiesel feedstock [17]. Fatty acid methyl ester from pongamia and other potential biodiesel plants such as Azadirachta indica, Calophyllum inophyllum and Jatropha curcas meet the major specifications of biodiesel standards required by American and European Standard Organization [31]. 
The oil extracted from pongamia seeds is non-edible, as it has a bitter taste and a disagreeable aroma. It is yellow colored (orange to brown) and viscous. During the past few decades pongamia oil has attracted considerable attention as a potential renewable, biodegradable, eco-friendly and non-toxic fuel [17]. Several studies have determined oil yield, as below:

- $\quad 1,000 \mathrm{~kg}$ pongamia seeds yield $270-300 \mathrm{~kg}$ of crude pongamia oil, where oil content is $27-30 \%$ [26].

- $\quad$ The oil yield of pongamia seeds could reach up to $35 \%$ by weight $[17,32]$.

- $\quad$ Some reports found yields of up to $40 \%$ [27,33].

- With the estimation of 350 pongamia trees in one hectare, it can produce $\sim 5$ tons oil ha/year [27].

Pongamia crude oil needs further processing (transesterification) to give methyl esters. About 85- 90 liters of biodiesel and 15-16 liters of glycerin (considered a by-product) can be obtained from 100 liters of pongamia crude oil by transesterification [26]. Meanwhile other report found that about $4 \mathrm{~kg}$ of pongamia seeds are required to produce 1 liter of crude oil, which in turn yielded $896 \mathrm{ml}$ of biodiesel [34].

Pongamia can yield a considerable amount of biodiesel comparing to other biofuel species (Figure 2).

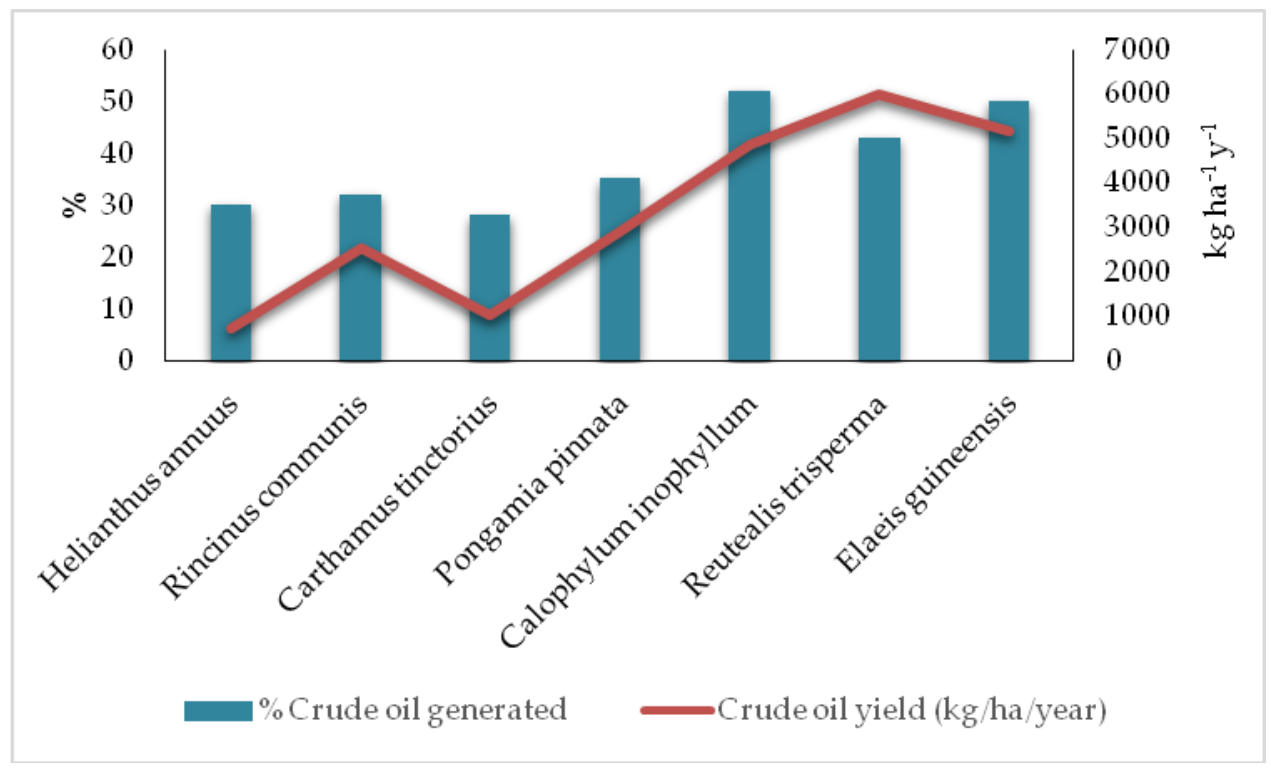

Figure 2. Amount of crude oil yielded by pongamia and other biofuel species

\subsubsection{Pongamia for bio-jet fuel}

One potential product from pongamia is biofuel for jets. Most planes are fueled by conventional jet fuel, which is non-renewable, costly and emits large amounts of carbon when combusted; about 2 tons of conventional jet fuel generates 1.6 tons of carbon when burned [35]. Therefore, the aviation industry is looking for renewable jet fuels [35]. However, compared to other industries, aviation has a limited range of alternative renewable fuel options that can replace fossil fuels. Bio-derived jet fuel could be a viable alternative for aviation industries [36]. Camelina sativa, Jatropha spp., Elaeis guineensis and algae have already used to produce fuel for several test flight; pongamia oil has yet to be tested, but has good potential [27] while land restoration, especially when compared to Elaeis guineensis (commonly known as oil palm) and its worldwide concern to deforestation link.

\subsubsection{Other uses of pongamia}

Table 2. The products and uses of pongamia tree

\begin{tabular}{l|l|l} 
Attributes & Important uses & References \\
\hline
\end{tabular}




\begin{tabular}{|c|c|c|}
\hline \multirow{3}{*}{ Wood } & $\begin{array}{l}\text { Pongamia logs serve as the raw material for } \\
\text { wood flour as lignocellulosic filler that can be } \\
\text { further processed to produce wood-plastic } \\
\text { composites. }\end{array}$ & [37] \\
\hline & $\begin{array}{l}\text { Pongamia wood is useful for making tool } \\
\text { handles, combs, cabinets, cartwheels, posts, } \\
\text { agricultural implements and paper pulp. }\end{array}$ & {$[23,28]$} \\
\hline & Pongamia wood is used as fuelwood. & [28] \\
\hline \multirow[t]{2}{*}{ Medicine } & $\begin{array}{c}\text { Almost all parts of pongamia trees are used in } \\
\text { folk medicine: } \\
\text { juice from the roots blended with coconut milk } \\
\text { is used to treat gonorrhea. } \\
\text { Stem bark extract has sedative and antipyretic } \\
\text { qualities and reduces enlarged spleens. } \\
\text { Juice from the leaves is used to treat diarrhea, } \\
\text { colds and coughs, and to relieve rheumatism. } \\
\text { The fruits are used to treat abdominal tumors. } \\
\text { The seed is used to treat keloid tumors, skin } \\
\text { ailments and hypertension, and as an } \\
\text { expectorant for bronchitis and whooping } \\
\text { cough. } \\
\text { The flowers are used to treat certain diabetic } \\
\text { conditions. } \\
\text { The oil is used to treat leprosy, chronic fever, } \\
\text { skin diseases and rheumatism. }\end{array}$ & {$[23,38]$} \\
\hline & $\begin{array}{c}\text { A crude decoction of pongamia leaves is used } \\
\text { as an antidiarrheal with efficacy against } \\
\text { cholera. }\end{array}$ & [39] \\
\hline Fodder & $\begin{array}{l}\text { The leaves are commonly used for cattle feed } \\
\text { and, less so, for goat feed, and are a valuable } \\
\text { source of fodder in arid regions. } \\
\text { Seed residue, presscake and seedcake contain } \\
\text { much protein and is used for poultry feed; but } \\
\text { it should not exceed } 75 \% \text { of feed as it contains } \\
\text { several toxic compounds. }\end{array}$ & {$[22,23,28]$} \\
\hline $\begin{array}{l}\text { Fertilizer and } \\
\text { biogas }\end{array}$ & $\begin{array}{l}\text { The seedcake and leaves are used as fertilizer. } \\
\text { Seedcake can generate biogas in household } \\
\text { biogas generators. }\end{array}$ & {$[25,26]$} \\
\hline Other services & $\begin{array}{l}\text { Pongamia trees serve as windbreaks, are fire } \\
\text { tolerant, control erosion, improve soils and are } \\
\text { ornamental trees. } \\
\text { The oil is used as a lubricant, leather dressing, } \\
\text { manufacturing soap, varnish and paint. } \\
\text { The flowers are a good source of pollen and } \\
\text { nectar, yielding a dark honey. } \\
\text { The bark is used to make rope. } \\
\text { Pounded and roasted seeds used to be utilized } \\
\text { as a fish poison. } \\
\text { Dried leaves are useful to store with grain to } \\
\text { repel insects. }\end{array}$ & {$[5,23,28,31,32,38,40-48]$} \\
\hline
\end{tabular}

\subsection{The potential of pongamia for land restoration}




\subsubsection{Nutrition enhancement of degraded land}

Degraded land is a land that has lost its productivity [49]. Such land often has low soil nutrient content, low productivity, suffers from erosion and is unsuitable for growing crops. There are two main ways of restoring degraded land: (i) physical, technical or engineering restoration or (ii) biological restoration [50]. However, the best way is to integrate these two methods.

Pongamia trees have several benefits to restore the degraded land. A study showed that a 5year-old pongamia plantation has a carbon sequestration potential of around $49.28 \mathrm{t} \mathrm{ha}^{-1}$ [51]. Pongamia is capable of withstanding drought stress, can grow on saline soils and needs little topsoil as it has a dense network of lateral roots and thick long taproots. Pongamia plantations can help alleviate compaction and crusting [52]. It is a sturdy plant with no special nutritional requirements and can grow in extreme environmental conditions. It is tolerant to soil sodicity, $\mathrm{pH}$ imbalances, high temperatures, heavy metal contamination, drought and poorly drained soils. Consequently pongamia can achieve phytostabilization, i.e. the long-term stabilization and containment of pollutants [53,54]. Iron, chromium, copper, manganese and magnesium in fly ash dykes have been phytostabilized by establishing pongamia plantations on the dykes [53]. Therefore, establishing pongamia biofuel plantations on degraded land can be a win-win solution for energy production and land restoration [50,52-55].

\subsubsection{Nitrogen fixing}

Chemical nitrogen fertilizer is widely used for growing crops in Indonesia. However, it is costly and its production causes high levels of greenhouse gas emissions [56]. The restoration of degraded land also needs the stabilization of nitrogen content. Pongamia is a leguminous tree that fixes biological nitrogen, while also producing the raw materials for biofuel $[57,58]$. In contrast, other common biofuel crops, such as canola, sugarcane, sweet sorghum, maize and woody trees (e.g. eucalyptus and willow), demand nitrogen to grow rather than produce nitrogen [57]. Pongamia produces nitrogen throughout its life [57]. It fixes nitrogen in root nodules through symbiosis with soil bacteria that are collectively called rhizobia ${ }^{1}$ [57]. Therefore, the cultivation of pongamia together with agricultural crops can potentially have a good agricultural yield.

\subsection{Community involvement}

Fuel production and distribution are often considered as the state obligation, however, local communities as the stakeholder directly affected by the fuel shortage, their potential contribution [59] should be in account during pongamia cultivation process. Such contribution can oversee the local capacity building in both technical and administrative [60,61] that can strengthen pongamia cultivation in a landscape scale. People's involvement can enhance local income, innovative spirit, technical proficiency and enthusiasm by distribution degraded land (the area surrounded by the community) or using their own degraded land for pongamia cultivation. It may also increase transparency and accountability for all parties, i.e. local communities, government, investors; and for the sense of responsibility and encouragement to support the land restoration efforts from the mutually binding interests.

\section{Conclusions}

Pongamia trees are well suited to growing in adverse environmental conditions. This tree can grow in most soil types, in partial shade or full sun, and at various temperatures. Pongamia is a

\footnotetext{
${ }^{1}$ Rhizobia is an endophytic bacterial community living in plant tissue (root nodules) [56].
} 
multipurpose tree that fixes soil nitrogen and improves the soil health, and produces large amounts of non-edible oil for biodiesel. It can produce such bioenergy on non-cropping and degraded land that is not suitable for food production. As the large area of degraded lands in Indonesia delivers limited benefits to humans and nature, restoring such land through pongamia cultivation can provide an opportunity to enhance ecosystem services delivery and reverse the loss of biodiversity. Although several other species produce biofuel (e.g. oil palm, coconut, jatropha), with its multiple benefits (Table 2), pongamia is a prime candidate for planting as a bioenergy feedstock on degraded land.

However, further studies of pongamia, focusing on up-to-date production technology, longterm plantation management, community involvement, various value-added options (e.g. understory crop association), identifying potential biofuel producers and consumers, developing effective business models for various biofuel stakeholders, and the feasibility of building stable biofuel markets, could help to fill knowledge gaps in Indonesia and benefit scientific communities, policymakers and other stakeholders.

Author Contributions: B.L., D.A.P., Y.B.S. S.M.L. and H.B. designed the study. B.L., D.A.P. and Y.B.S. collected and analyzed the data. B.L., S.A.R. D.A.P., Y.B.S., S.M.L., A.M.M., J.W. and H.B. prepared and reviewed the manuscript. All the authors read and approved the final manuscript.

Funding: This research was funded by the CGIAR Research Program on Forests, Trees and Agroforestry (CRPFTA), its donors and the National Institute of Forest Science (NIFOS) of Republic of Korea.

Acknowledgments: Authors are grateful to the number of colleagues at the Forestry and Environmental Research, Development and Innovation Agency (FOERDIA), CIFOR, National Institute of Forest Science (NIFOS), and the Natural Universitas Muhammadiyah Palangkaraya, Central Kalimantan, Indonesia, who provided their assistance, time and thoughtful scientific support for this work.

Conflicts of Interest: The authors declare no conflict of interest. The funders had no role in the design of the study; in the collection, analyses, or interpretation of data; in the writing of the manuscript, or in the decision to publish the results.

\section{References}

1. Hidayat, A. Konsumsi BBM dan peluang pengembangan energi alternatif. Inovasi 2005, 5, 11-17.

2. Kotarumalos, N. A. Menuju Ketahanan Energi Indonesia : Belajar dari Negara Lain. J. Glob. dan Strateg. 2009, 3, 1-18.

3. Republik Indonesia Peraturan Pemerintah Republik Indonesia Nomor 79 tahun 2014; 2014.

4. Pena, D. S.; Evangelista, A. W. P.; Alves Júnior, J.; Casaroli, D. Agroclimatic zoning for jatropha crop (Jatropha curcas L.) in the State of Goiás. Acta Sci. - Agron. 2016, 38, 329-335, doi:10.4025/actasciagron.v38i3.28224.

5. Kesari, V.; Rangan, L. Development of Pongamia pinnata as an alternative biofuel crop - current status and scope of plantations in India. J. Crop Sci. Biotechnol. 2010, 13, 127-137, doi:10.1007/s12892010-0064-1.

6. The Ministry of Environment and Forestry Statistics of Ministry of Environment and Forestry, 2015; Jakarta, Indonesia, 2016.

7. Badan Restorasi Gambut (BRG) Penetapan Peta Indikatif Restorasi Gambut 2016.

8. Baral, H.; Lee, S. M. Sustainable bioenergy systems to restore and valorize degraded land; Center for International Forestry Research (CIFOR): Bogor, Indonesia, 2016.

9. ICCC Crop to Energy on Degraded Land as a Step Toward Energy Independence, Carbon Sink Agriculture and Protection of REDD+ Designated Areas; Jakarta, 2014.

10. Lynd, L. R.; Sow, M.; Chimphango, A. F. A.; Cortez, L. A. B.; Brito Cruz, C. H.; Elmissiry, M.; Laser, M.; Mayaki, I. A.; Moraes, M. A. F. D.; Nogueira, L. A. H.; Wolfaardt, G. M.; Woods, J.; Van Zyl, W. H. Bioenergy and African transformation. Biotechnol. Biofuels 2015.

11. Malla, S. Household energy consumption patterns and its environmental implications: Assessment of energy access and poverty in Nepal. Energy Policy 2013, doi:10.1016/j.enpol.2013.06.023.

12. Casillas, C. E.; Kammen, D. M. The energy-poverty-climate nexus. Science (80-. ). 2010. 
13. Leksono, B.; Jayusman; S, P.; Windyarini, E.; Hasnah, T. M. Pemuliaan nyamplung dan malapari untuk biofuel; Yogyakarta, Indonesia, 2016.

14. Leksono, B. Pemuliaan dan Bioteknologi nyamplung dan malapari untuk biofuel; Yogyakarta, Indonesia, 2015.

15. Djam'an, D. Majalah Kehutanan Indonesia edisi VIII. Jakarta 2009.

16. Csurhes, S.; Hankamer, C. Invasive Plant Risk Assessment: Pongamia (Millettia pinnata syn. Pongamia pinnata); Queensland, Australia, 2016.

17. Bobade SN; Khyade VB Detail study on the Properties of Pongamia Pinnata (Karanja) for the Production of Biofuel. Res. J. Chem. Sci. Res.J.Chem.Sci 2012.

18. Aminah, A.; Supriyanto; Suryani, A.; Siregar, I. Z. Genetic diversity of pongamia pinnata (Millettia pinnata, aka. malapari) populations in Java Island, Indonesia. Biodiversitas 2017, doi:10.13057/biodiv/d180233.

19. Jayusman Peta Sebaran Malapari (Pongamia pinnata Merril) di Pulau Jawa dan Upaya Konservasinya. In Prosiding Seminar Nasional Pendidikan Biologi dan Saintek II; Nurcahyanto, G., Kartikasari, S., Asngad, A., Suparta, Hariyatmi, Djumadi, Setyaningsih, E., Rahayu, T., Agustina, P., Suryani, T., Roziaty, E., Kusumadani, A. I., Sidiq, Y., Eds.; Universitas Muhammadiyah Surakarta (UMS): Surakarta, 2017; pp. 503-507.

20. Sidiyasa, K.; Sitepu, B. S.; Atmoko, T. Habitat dan Populasi Ki Beusi (Pongamia pinnata (L.) Pierre) dan Kampis (Hernandia nymphaeifolia Kubitzki) di Kalimantan Timur. In Prosiding Seminar HasilHasil Penelitian BPTKSDA Samboja; Balikpapan, 2012.

21. Dwivedi, G.; Sharma, M. P. Prospects of biodiesel from Pongamia in India. Renew. Sustain. Energy Rev. 2014, doi:10.1016/j.rser.2014.01.009.

22. Duke, J. Handbook of Energy Crops.

23. Orwa, C.; Mutua, A.; Kindt, R.; Jamnadass, R.; Anthony, S. Agroforestree Database: a tree reference and selection guide version 4.0. Http:Www.Worldagroforestry.Org/Sites/Treedbs/Treedatabases.Asp) 2009, doi:10.1007/978-94-007-5628-1_11.

24. Scott, P. T.; Pregelj, L.; Chen, N.; Hadler, J. S.; Djordjevic, M. A.; Gresshoff, P. M. Pongamia pinnata: An Untapped Resource for the Biofuels Industry of the Future. BioEnergy Res. 2008, doi:10.1007/s12155008-9003-0.

25. Garg, R. K.; Chaudhari, S.; Singh, R. In vitro propagation of potential biodiesel plant, Pongamia pinnata (L.) Pierre. Shrinkhla Ek Shodhparak Vaicharik Patrika 2017, 4.

26. Chandrashekar, L. A.; Mahesh, N. S.; Gowda, B.; Hall, W. Life cycle assessment of biodiesel production from pongamia oil in rural Karnataka. Agric. Eng. Int. CIGR J. 2012.

27. Murphy, H. T.; O’Connell, D. A.; Seaton, G.; Raison, R. J.; Rodriguez, L. C.; Braid, A. L.; Kriticos, D. J.; Jovanovic, T.; Abadi, A.; Betar, M.; Brodie, H.; Lamont, M.; McKay, M.; Muirhead, G.; Plummer, J.; Arpiwi, N. L.; Ruddle, B.; Saxena, S.; Scott, P. T.; Stucley, C.; Thistlethwaite, B.; Wheaton, B.; Wylie, P.; Gresshoff, P. M. A Common View of the Opportunities, Challenges, and Research Actions for Pongamia in Australia. Bioenergy Res. 2012.

28. Dwivedi, G.; Jain, S.; Sharma, M. P. Pongamia as a Source of Biodiesel in India. Smart Grid Renew. Energy 2011, doi:10.4236/sgre.2011.23022.

29. Abadi, A.; Maynard, H.; Arpiwi, N. L.; Stucley, C.; Bartle, J.; Giles, R. Economics of Oil Production from Pongamia (Millettia pinnata) for Biofuel in Australia. Bioenergy Res. 2016, doi:10.1007/s12155-0169739-x.

30. Rahman, M. M.; Ahiduzzaman, M.; Islam, A. K. M. S.; Blanchard, R. Karoch (Pongamia pinnata)- An alternative source of biofuel in Bangladesh. In 2014 3rd International Conference on the Developments in Renewable Energy Technology (ICDRET); 2014; pp. 1-6.

31. Azam, M. M.; Waris, A.; Nahar, N. M. Prospects and potential of fatty acid methyl esters of some nontraditional seed oils for use as biodiesel in India. Biomass and Bioenergy 2005, doi:10.1016/j.biombioe.2005.05.001.

32. Ahmad, M.; Zafar, M.; Khan, M. A.; Sultana, S. Biodiesel from Pongamia pinnata L. Oil: A promising alternative bioenergy source. Energy Sources, Part A Recover. Util. Environ. Eff. 2009, doi:10.1080/15567030802092882.

33. Nabi, M. N.; Hoque, S. M. N.; Akhter, M. S. Karanja (Pongamia Pinnata) biodiesel production in Bangladesh, characterization of karanja biodiesel and its effect on diesel emissions. Fuel Process. Technol. 2009, doi:10.1016/j.fuproc.2009.04.014. 
34. Patil, V. K.; Bhandare, P.; Kulkarni, P. B.; Naik, G. R. Progeny evaluation of Jatropha curcas and Pongamia pinnata with comparison to bioproductivity and biodiesel parameters. J. For. Res. 2015, doi:10.1007/s11676-014-0001-0.

35. Hendricks, R. C.; Bushnell, D. M.; Shouse, D. T. Aviation fueling: A cleaner, greener approach. Int. J. Rotating Mach. 2011, doi:10.1155/2011/782969.

36. Graham, P. W.; Smart, A.; Tasman, A.; Graham, P. Possible Futures : Scenario Modelling of Australian Alternative Transport Fuels to 2050. 2011.

37. Islam, M. A.; Bari, R. Flat pressed Pongamia pinnata wood-flour/polypropylene composite loaded with talc: a statistical optimization. J. Indian Acad. Wood Sci. 2016, doi:10.1007/s13196-016-0170-x.

38. Sangwan, S.; Rao, D. V.; Sharma, R. A. A Review on Pongamia Pinnata (L.) Pierre: A Great Versatile Leguminous Plant. Nat. Sci. 2010.

39. Brijesh, S.; Daswani, P. G.; Tetali, P.; Rojatkar, S. R.; Antia, N. H.; Birdi, T. J. Studies on Pongamia pinnata (L.) Pierre leaves: understanding the mechanism(s) of action in infectious diarrhea. J. Zhejiang Univ. Sci. B 2006, doi:10.1631/jzus.2006.B0665.

40. Herman, M.; Syakir, M.; Pranowo, D.; Saefudin; Sumanto Kemiri Sunan (Reutalis trisperma (Blanco) Airy Shaw) Tanaman Penghasil Minyak Nabati dan Konservasi Lahan 2013, 91.

41. Inna Punda Agribusiness handbook: Sunflower refined and crude oils. FAO Invest. Cent. Div. 2010, 40.

42. Akinerdem, F.; Öztürk, Ö. Safflower and biodiesel quality in Turkey. In 7th International Safflower Conference; 2008.

43. Bustomi, S.; Kurniaty, R.; Rostiwati, T.; Kosasih, A. S.; Irawati, S.; Sudradjat, R.; Illa, A.; Leksono, B. Nyamplung (Calopyhllum innopyhllum L.) Sumber Energi Biofuel yang Potensial; Priyono, N., Widyaningtyas, N., Eds.; Departemen Kehutanan: Jakarta, 2009.

44. Sumathi, S.; Chai, S. P.; Mohamed, A. R. Utilization of oil palm as a source of renewable energy in Malaysia. Renew. Sustain. Energy Rev. 2008.

45. Pranowo, D.; Herman, M.; Syafaruddin Potensi Pengembangan Kemiri Sunan ( Reutealis trisperma (Blanco) Airy Shaw) Di Lahan Terdegredasi. Perspektif 2015, 14, 87-102.

46. Wulandari, W.; Darusman, D.; Kusmana, C.; Widiatmaka, W. Kajian finansial pengembangan biodiesel kemiri sunan (Reutealis trisperma (Blanco) Airy shaw) pada lahan tersedia di Jawa Barat. J. Penelit. Sos. dan Ekon. Kehutan. 2015, 12, 31-42.

47. Atabani, A. E.; César, A. D. S. Calophyllum inophyllum L. - A prospective non-edible biodiesel feedstock. Study of biodiesel production, properties, fatty acid composition, blending and engine performance. Renew. Sustain. Energy Rev. 2014.

48. Bridgemohan, P.; Bridgemohan, R. S. H. Invasive weed risk assessment of three potential bioenergy fuel species. Int. J. Biodivers. Conserv. 2014, 6, 790-796, doi:10.5897/IJBC2014.0763.

49. WRI What is degraded land 2017.

50. Ahirwal, J.; Maiti, S. K.; Singh, A. K. Ecological Restoration of Coal Mine-Degraded Lands in Dry Tropical Climate: What Has Been Done and What Needs to Be Done? Environ. Qual. Manag. 2016, doi:10.1002/tqem.21481.

51. Edrisi, S. A.; Abhilash, P. C. Exploring marginal and degraded lands for biomass and bioenergy production: An Indian scenario. Renew. Sustain. Energy Rev. 2016, doi:10.1016/j.rser.2015.10.050.

52. Lal, R. Land area for establishing biofuel plantations[1]. Energy Sustain. Dev. 2006, doi:10.1016/S09730826(08)60533-5.

53. Singh, A. Comparative Performance and Restoration Potential of Jatropha curcas and Pongamia pinnata on Degraded Soil of North India, University of Lucknow, 2013.

54. Juwarkar, A. A.; Singh, S. K. Microbe-assisted phytoremediation approach for ecological restoration of zinc mine spoil dump. Int. J. Environ. Pollut. 2010, doi:10.1504/IJEP.2010.035927.

55. Balooni, K.; Singh, K. Tree plantations for restoration of degraded lands and greening of India: A case study of tree growers' cooperatives. Nat. Resour. Forum 2001, doi:10.1111/j.1477-8947.2001.tb00743.x.

56. Kesari, V.; Ramesh, A. M.; Rangan, L. Rhizobium pongamiae sp. nov. from root nodules of Pongamia pinnata. Biomed Res. Int. 2013, doi:10.1155/2013/165198.

57. Samuel, S.; Scott, P. T.; Gresshoff, P. M. Nodulation in the Legume Biofuel Feedstock Tree Pongamia pinnata. Agric. Res. 2013, doi:10.1007/s40003-013-0074-6.

58. Chaukiyal, S. P.; Sheel, S. K.; Pokhriyal, T. C. Effects of seasonal variation and nitrogen treatments on nodulation and nitrogen fixation behaviour in Pongamia pinnata. J. Trop. For. Sci. 2000. 
59. Rahman, S.A.; Sunderland, T.; Roshetko, J.M.; Healey, J.R. Facilitating smallholder tree farming in fragmented tropical landscapes: challenges and potentials for sustainable land management. $J$. Environ. Manage. 2017, 198, 110-121.

60. Ostrom, E. Governing the Commons: the Evaluation of Institutions for Collective Action. Cambridge University Press, Cambridge, UK, 1990.

61. Watts, J.D.; Colfer, C.J.P. The governance of tropical forested landscape. In: Colfer, C.J.P., Pfund, J.L. (Eds.), Collaborative Governance of Tropical Landscapes. The Earthscan, London, 2011, pp. 35-54. 